\title{
Adaptive response to oxidative stress in the filamentous fungus Aspergillus niger B1-D
}

\author{
Qiang Li, Brian McNeil, Linda M. Harvey* \\ Strathclyde Fermentation Centre, Strathclyde Institute of Pharmacy and Biomedical Sciences, Royal College Building, University of Strathclyde, \\ 204 George Street, Glasgow G1 1XW, UK
}

\begin{abstract}
In the present study, we used a recombinant filamentous fungus strain, Aspergillus niger $\mathrm{B} 1 \mathrm{D}$, as a model system, and investigated the antioxidant defences in this organism. Our findings indicate that pretreatment with low concentrations of $\mathrm{H}_{2} \mathrm{O}_{2}$ completely prevents killing by this oxidant at high concentrations. It shows that A. niger adapts to exposure to $\mathrm{H}_{2} \mathrm{O}_{2}$ by reducing growth and inducing a number of antioxidant enzyme activities, including superoxide dismutase, catalase, glutathione peroxidase, glutathione reductase, of which the induction of catalase is the most pronounced. Moreover the decline of these antioxidant enzymes activities after $\mathrm{H}_{2} \mathrm{O}_{2}$ detoxification, coincides with recommencement of growth. Results from monitoring the extracellular $\mathrm{H}_{2} \mathrm{O}_{2}$ concentration clearly indicate a very rapid detoxification rate for $\mathrm{H}_{2} \mathrm{O}_{2}$ in adapted $A$. niger cultures. A mathematical model predicts only very low concentrations of intracellular $\mathrm{H}_{2} \mathrm{O}_{2}$ accumulating in such cultures. Our results also show that glutathione plays a role in the oxidative defence against $\mathrm{H}_{2} \mathrm{O}_{2}$ in A. niger. On addition of $\mathrm{H}_{2} \mathrm{O}_{2}$, the intracellular pool of glutathione increases while the redox state of glutathione becomes more oxidized.
\end{abstract}

Keywords: Oxidative stress; Filamentous fungi; Adaptive responses; $\mathrm{H}_{2} \mathrm{O}_{2}$; Antioxidant enzymes

\section{Introduction}

$\mathrm{H}_{2} \mathrm{O}_{2}$ is an unavoidable by-product of all living organisms which rely on respiration for energy production. The mitochondrion is the main site of $\mathrm{H}_{2} \mathrm{O}_{2}$ production [1] where continuous production of superoxide caused by electron leakage takes place, and incomplete reduction of superoxide gives rise to $\mathrm{H}_{2} \mathrm{O}_{2}$ [2] . $\mathrm{H}_{2} \mathrm{O}_{2}$ production is also involved with a number of oxidase reactions, such as fatty acid catabolism $\beta$-oxidation. The cytotoxicity of $\mathrm{H}_{2} \mathrm{O}_{2}$ is generally thought to be due to its ability to damage macromolecules, including lipids, DNA, and proteins [3]. Compared with other reactive oxygen species (ROS), $\mathrm{H}_{2} \mathrm{O}_{2}$ is less toxic, but is able to diffuse into different compartments from its original production sites before reaching its targets [4].

Abbreviations: CAT, Catalase; GPx, Glutathione peroxidase; GR, Glutathione reductase; GSH, Glutathione; GSSG, Oxidized glutathione; MTT, 3-(4,5dimethyl-2-thiazolyl)-2,5-diphenyl-2 $H$-tetrazolium bromide; ROS, Reactive oxygen species; SOD, Superoxide dismutase; $t$-BHP, tert-butyl hydroperoxide.
Moreover, $\mathrm{H}_{2} \mathrm{O}_{2}$ can react with transition metal ions through the Fenton reaction [5] to produce the highly toxic hydroxyl radical, which greatly exacerbates the cytotoxicity of $\mathrm{H}_{2} \mathrm{O}_{2}$.

Yeasts have become a favourite model to study oxidative stress in microbial systems, and the research carried out in a range of yeast species, including mainly Saccharomyces cerevisiae, has contributed to our knowledge on how eukaryotes defend themselves from continuous damage caused by ROS. In S. cerevisiae, two catalases (CTT, CTA) [6] and some peroxidases, cytochrome $c$ peroxidase (CCP) [7] and glutathione peroxidase (GPx) [8], have been shown to be involved in $\mathrm{H}_{2} \mathrm{O}_{2}$ catabolism. Mutants in which the genes for these catalases were deleted were significantly less able to acquire $\mathrm{H}_{2} \mathrm{O}_{2}$ tolerance compared with the wild type [9].

In filamentous fungi, more than one catalase gene has been shown to exist, and they are differentially regulated. For example, in Aspergillus nidulans, two differentially regulated genes, catA and catB, have been characterized [10-12]. CatA is preferentially expressed in spores, while catB is expressed only in mycelia, and both could be induced by oxidative stress. In 
Aspergillus niger, intracellular catalase activities were shown to be induced by exogenous $\mathrm{H}_{2} \mathrm{O}_{2}[13,14]$. Despite these earlier studies, the intrinsic role of catalase in filamentous fungi is still unclear, and to what extent catalase actually contributes to cellular oxidative stress defence via $\mathrm{H}_{2} \mathrm{O}_{2}$ detoxification is still unknown.

The tripeptide $\gamma$-L-glutamyl-L-cystinylglycine (glutathione$\mathrm{GSH}$ ) is one of the major antioxidant molecules in yeast cells, and is thought to play a vital role in buffering the cell against ROS [15]. Glutathione can react with oxidants nonenzymically, or the reaction can be catalysed by glutathione peroxidase, and the oxidized glutathiol (GSSG) could be recycled by glutathione reductase (GR) at the expense of NADPH. Mutants of $S$. cerevisiae deficient in glutathione synthesis [15-17] or glutathione recycling [18] showed increased sensitivity to $\mathrm{H}_{2} \mathrm{O}_{2}$, but were unaffected in their ability to adapt to $\mathrm{H}_{2} \mathrm{O}_{2}$. Generally, studies on the glutathione pathway involving filamentous fungi are rather scarce, and the findings are sometimes unclear and contradictory, compared with studies on yeasts. For example, GPx is thought to play only a minor role in the defence against oxidative stress in $A$. niger [19], In Penicillium chrysogenum, GSH concentration slightly increases in the presence of elevated concentrations of exogenous $\mathrm{H}_{2} \mathrm{O}_{2}$ while GSSG increased significantly, resulting in an imbalance of glutathione homeostasis. Meanwhile, GPx, GR, and glutathione cycling activities all were elevated by $\mathrm{H}_{2} \mathrm{O}_{2}$ addition [20].

Submerged culture is the system employed industrially for the production of a variety of metabolites of enormous economic importance produced by filamentous fungi [21]. The cultivation of these organisms in submerged culture involves vigorous agitation and aeration; thus it is not surprising that oxidative stress is frequently reported as occurring [22]. In the present work, we report on the physiological responses of a filamentous fungus, $A$. niger $\mathrm{B} 1-\mathrm{D}$, to exposure to oxidative stress simulated by the addition of $\mathrm{H}_{2} \mathrm{O}_{2}$. We have monitored the activities of all major antioxidant enzymes reported from previous studies in filamentous fungi, which should allow a more coherent and complete understanding of the antioxidant defense adopted by this organism. We have examined the role of the glutathione pathway in this fungus in detail, to help clarify the antioxidant effects of GSH in the presence of elevated levels of $\mathrm{H}_{2} \mathrm{O}_{2}$.

\section{Materials and methods}

\section{Strain and cultivation}

A recombinant strain of $A$. niger B1-D [23] has been used throughout this study. Aspergillus complete medium was used for the batch cultivation [24]. The composition of the medium is $50 \mathrm{~g}$ glucose, $5 \mathrm{~g} \mathrm{NH}_{4} \mathrm{Cl}, 20 \mathrm{ml}$ salt solution, $10 \mathrm{ml}$ vitamin solution, and water to $1.0 \mathrm{~L}$. Salt solution was $\mathrm{KCl}, 26 \mathrm{~g}$; $\mathrm{MgSO}_{4} \cdot 7 \mathrm{H}_{2} \mathrm{O}, 26 \mathrm{~g} ; \mathrm{KH}_{2} \mathrm{PO}_{4}, 76 \mathrm{~g}$; trace-element solution, $50 \mathrm{ml}$; and water to $1 \mathrm{~L}$. Trace-element solution was $\mathrm{Na}_{2} \mathrm{~B}_{4} \mathrm{O}_{7}$. $10 \mathrm{H}_{2} \mathrm{O}, 40 \mathrm{mg} ; \mathrm{CuSO}_{4} \cdot 5 \mathrm{H}_{2} \mathrm{O}, 400 \mathrm{mg} ; \mathrm{FePO}_{4} \cdot 2 \mathrm{H}_{2} \mathrm{O}, 800 \mathrm{mg}$; $\mathrm{MnSO}_{4} \cdot 2 \mathrm{H}_{2} \mathrm{O}, 800 \mathrm{mg} ; \mathrm{Na}_{2} \mathrm{MoO}_{4} \cdot 2 \mathrm{H}_{2} \mathrm{O}, 800 \mathrm{mg} ; \mathrm{ZnSO}_{4}$ $7 \mathrm{H}_{2} \mathrm{O}, 8 \mathrm{~g}$; and water to $1 \mathrm{~L}$. Vitamin solution: $p$-aminobenzoic acid, $20 \mathrm{mg}$; thiamine hydrocholoride, $50 \mathrm{mg}$; biotin, $10 \mu \mathrm{g}$; nicotinic acid, $100 \mathrm{mg}$; calcium D-pantothenic acid, $200 \mathrm{mg}$; pyridoxine monohydrochloride, $50 \mathrm{mg}$; riboflavin, $100 \mathrm{mg}$; and water to $1 \mathrm{~L}$.

Shake flask cultivation was carried out in 500-ml conical flasks containing $200 \mathrm{ml}$ sterile medium. An inoculum of $1 \times 10^{5}$ spores per milliliter was used. The inoculated flasks were placed in a rotary shaker (New Brunswick Scientific, Edison, USA) at $200 \mathrm{rpm}$ and $25 \pm 0.1^{\circ} \mathrm{C}$. After $70 \mathrm{~h}$ incubation, a stock solution of $\mathrm{H}_{2} \mathrm{O}_{2}$ was aseptically added to the culture to the desired final concentration by syringe filtration through a sterile $0.2-\mu \mathrm{m}$ cellulose acetate membrane (NALGENE, Fisher, UK). In adaptation experiments, $100 \mu \mathrm{M} \mathrm{H}_{2} \mathrm{O}_{2}$ was added to batch cultures of $A$. niger at $70 \mathrm{~h}$, followed by 10 or $20 \mathrm{mM}$ $\mathrm{H}_{2} \mathrm{O}_{2} 2 \mathrm{~h}$ later. For comparison, 10 or $20 \mathrm{mM} \mathrm{H}_{2} \mathrm{O}_{2}$ was added without pretreatment of $100 \mu \mathrm{M} \mathrm{H}_{2} \mathrm{O}_{2}$.

\section{Biochemical assays}

Biomass was estimated according to the method of Bai et al. [24]. Five milliliters of fungal culture was withdrawn and filtered through a 4.25 -cm-diameter $\mathrm{GF} / \mathrm{C}$ filter, which has a particle retention time size of approximately $1.2 \mu \mathrm{m}$ (Whatman Ltd., UK). The filter cake was washed twice with $5 \mathrm{ml}$ distilled water, dried for $20 \mathrm{~min}$ in a microwave oven $(650 \mathrm{~W})$ on medium-low power, and cooled in a desiccator before weighing. Glucose concentration of the filtrate was determined by an enzymatic assay kit (r-biopharm, Germany).

$\mathrm{H}_{2} \mathrm{O}_{2}$ concentration of the filtrate was assayed by the FOX method [25]. Fifty microliters of properly diluted sample was added to $950 \mu \mathrm{FOX} 1$ reagent $(100 \mu \mathrm{M}$ Xylenol orange, $250 \mu \mathrm{M}$ ammonium ferrous sulfate, $100 \mathrm{mM}$ sorbitol, and $25 \mathrm{mM}$ $\mathrm{H}_{2} \mathrm{SO}_{4}$ ) in a cuvette (Fisher, UK), vortexed, and incubated at room temperature for $5 \mathrm{~min}$ to allow colour development. The absorbance was read at $560 \mathrm{~nm}$. The signal was read against a $\mathrm{H}_{2} \mathrm{O}_{2}$ standard curve measured at the same time along with samples and was linear in the $0-100 \mu \mathrm{M}$ concentration range. For the authenticity of $\mathrm{H}_{2} \mathrm{O}_{2}$, the same sample pretreated with $200 \mathrm{U} / \mathrm{ml}$ catalase was used as blank. For the assay of biomass, glucose, and $\mathrm{H}_{2} \mathrm{O}_{2}$, all samples were analyzed in triplicate.

After fungal cells were harvested, filtered, and washed, the filter cake was resuspended in the same volume of sodium phosphate buffer $(50 \mathrm{mM}, \mathrm{pH} 7.0)$. The fungal cells were disrupted by a high-pressure cell disrupter (Model 4000, Constant System Ltd., UK). Cell-free extracts were separated from cell debris by centrifugation at $4^{\circ} \mathrm{C}, 18,407 \times g$ for $30 \mathrm{~min}$. The clear supernatant was used to assay enzyme activities immediately. SOD activity was measured by its ability to inhibit the reduction of cytochrome $c$ by the superoxide radical produced by the xanthine/xanthine oxidase system, which was describe by Crapo et al. [26]. Operating concentrations were as follows: $0.1 \mathrm{mM}$ xanthine, $0.1 \mathrm{mM}$ EDTA, $50 \mathrm{mM} \mathrm{Na} \mathrm{CO}_{3}$ (pH 10.2), $10 \mu \mathrm{M}$ ferricytochrome $c$, and enough xanthine oxidase to cause $\Delta A_{550 \mathrm{~nm}}=0.025 / \mathrm{min}$. CAT activity was determined by a spectrophotometric method [27]. GPx activity was measured spectrophotometrically according to the disappearance rate of NADPH [28]. GR activity was determined by a spectrometric method described by Lee et al. [29]. The DTNB-GSSG reductase 


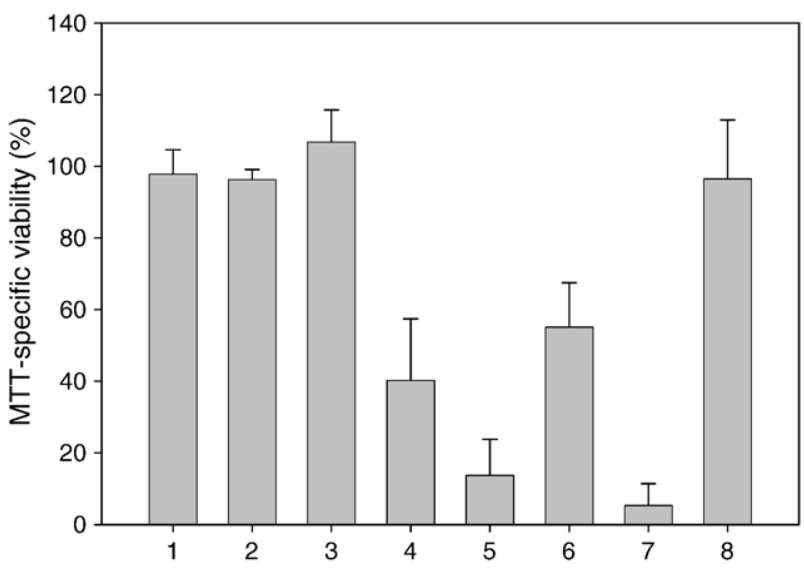

Fig. 1. Effect of high concentrations of $\mathrm{H}_{2} \mathrm{O}_{2}$ addition on the viability of $A$. niger B1-D. Seventy-two-hour-old batch cultures of $A$. niger were incubated with 10 or $20 \mathrm{mM} \mathrm{H}_{2} \mathrm{O}_{2}$ for $2 \mathrm{~h}$ and then sampled for the viability assay. Results were then standardized based on prestress values. Some cultures were pretreated with $100 \mu \mathrm{M} \mathrm{H}_{2} \mathrm{O}_{2}$ for $2 \mathrm{~h}$ before challenge with 10 or $20 \mathrm{mM} \mathrm{H}_{2} \mathrm{O}_{2}$. Others had $100 \mu \mathrm{g} / \mathrm{ml}$ cycloheximide added during the pretreatment. The effect of cycloheximide was elucidated by incubating with 72-h-old batch culture for $2 \mathrm{~h}$. Results were obtained from three independent experiments and are expressed as mean $\pm \mathrm{SD}$. (1) Control; (2) $10 \mathrm{mM} \mathrm{H}_{2} \mathrm{O}_{2}$ (pre-treated with $100 \mu \mathrm{M}$ $\mathrm{H}_{2} \mathrm{O}_{2}$ for $2 \mathrm{~h}$; (3) $20 \mathrm{mM} \mathrm{H}_{2} \mathrm{O}_{2}$ (pre-treated with $100 \mu \mathrm{M} \mathrm{H}_{2} \mathrm{O}_{2}$ for $2 \mathrm{~h}$ ). (4) 10 $\mathrm{mM} \mathrm{H}_{2} \mathrm{O}_{2}$. (5) $20 \mathrm{mM} \mathrm{H}_{2} \mathrm{O}_{2}$; (6) $10 \mathrm{mM} \mathrm{H}_{2} \mathrm{O}_{2}$ (pretreated with $100 \mu \mathrm{M} \mathrm{H}_{2} \mathrm{O}_{2}$ and $100 \mu \mathrm{g} / \mathrm{ml}$ cycloheximide for $2 \mathrm{~h}$ ); (7) $20 \mathrm{mM} \mathrm{H}_{2} \mathrm{O}_{2}$ (pretreated with $100 \mu \mathrm{M} \mathrm{H} \mathrm{H}_{2} \mathrm{O}_{2}$ and $100 \mu \mathrm{g} / \mathrm{ml}$ cycloheximide for $2 \mathrm{~h}$ ); (8) $100 \mu \mathrm{g} / \mathrm{ml}$ cycloheximide.

recycling assay was used to measure total GSH and GSSG [30]. Protein concentrations in the cell-free extracts were assayed by the Bradford method [31]. For the enzymatic assays, triplicate samples were collected and disrupted, and the supernatants were used individually.

MTT-specific cell viability was measured by a method of Emri et al. [32] with modification. Two milliliters of broth was aseptically withdrawn, filtered, washed, and added to a vial into which $2 \mathrm{ml}$ of fresh medium and $50 \mu \mathrm{l}$ of $5 \mathrm{mg} / \mathrm{ml}$ solution of 3(4,5-dimethyl-2-thiazolyl)-2,5-diphenyl-2 $H$-tetrazolium bromide (MTT) were also added. The sample was incubated for $24 \mathrm{~h}$ at $30^{\circ} \mathrm{C}$ causing the cells to turn purple, after which time $1 \mathrm{ml}$ of $10 \%(\mathrm{w} / \mathrm{v})$ solution of sodium dodecyl sulfate (SDS) in $20 \mathrm{mM} \mathrm{HCl}$ was added. The sample was incubated for a further $24 \mathrm{~h}$ at $30^{\circ} \mathrm{C}$, after which time it was centrifuged at $9279 \times \mathrm{g}$ for $5 \mathrm{~min}$ and the MTT-formazan content of the supernatant was measured spectrophotometrically at $570 \mathrm{~nm}$. A blank lacking cells was also carried out along with samples, the absorbance of which was subtracted from absorbances of samples. Results were expressed as $A_{570} \mathrm{~nm} / \mathrm{g}$ DCW. All samples were analyzed in triplicate.

\section{Results}

Fig. 1 shows the effects of $\mathrm{H}_{2} \mathrm{O}_{2}$ addition on the viability of A. niger B1-D. Direct addition of high concentrations of $\mathrm{H}_{2} \mathrm{O}_{2}$, either 10 or $20 \mathrm{mM}$, leads to reduced viability, indicating that these concentrations are lethal to this culture. However, pretreatment with a low, nonlethal concentration of $\mathrm{H}_{2} \mathrm{O}_{2}(100 \mu \mathrm{M})$ for $2 \mathrm{~h}$ prior to exposure to lethal concentrations completely re- moved the deleterious effects by $\mathrm{H}_{2} \mathrm{O}_{2}$. These results proved that batch cultures of $A$. niger can adapt to $\mathrm{H}_{2} \mathrm{O}_{2}$ via preexposure to low levels of this stressor. The ability to adapt to $\mathrm{H}_{2} \mathrm{O}_{2}$ is compromised by $100 \mu \mathrm{g} / \mathrm{ml}$ cycloheximide, a conventional protein translation inhibitor, indicating that a de novo protein synthesis was required for this adaptive response. Cycloheximide itself has no noticeable effect on the viability of the culture for a 2-h treatment.

Fig. 2 shows the effects of $\mathrm{H}_{2} \mathrm{O}_{2}$ addition on the dry cell weight (DCW) and glucose concentration versus time in A. niger B1-D. From the figure, it can be seen that $A$. niger grew exponentially during the time between 70 and $96 \mathrm{~h}$, and protein concentration remained stable in that period. However, a temporary reduction in growth was observed after exposure to $100 \mu \mathrm{M}$ $\mathrm{H}_{2} \mathrm{O}_{2}$. Consequent exposure to $10 \mathrm{mM} \mathrm{H} \mathrm{H}_{2} \mathrm{O}_{2}$ led to further inhibition. Nevertheless, glucose was still utilized, indicating that the culture was still metabolically active. The culture recovered from the effects of the oxidative stress within $4 \mathrm{~h}$ after addition of the $\mathrm{H}_{2} \mathrm{O}_{2}$.

The response in terms of intracellular protein content was slightly different from that of cell mass: protein content decreased to $67 \%$ of its original value after additions of $100 \mu \mathrm{M} \mathrm{H}_{2} \mathrm{O}_{2}$, but took longer to recover to prestress levels. Overall, pretreatment with low concentration of $\mathrm{H}_{2} \mathrm{O}_{2}$ changed A. niger's subsequent metabolism profoundly at the expense of growth.

Antioxidant enzymes have been thought of as the first line of defence in response to oxidative stress. In the present study we monitored four key antioxidant enzyme activities, SOD, CAT, GPx, and GR, previously reported as being of importance in oxidative stress defence in filamentous fungi [14,20,22], and the results are presented in Fig. 3. In the control, the activities of all four enzymes remained stable during the time between 70 and $96 \mathrm{~h}$. However, CAT, GPx, and GR activities were all significantly induced by $100 \mu \mathrm{M} \mathrm{H}_{2} \mathrm{O}_{2}$, further enhanced by subsequent addition of $10 \mathrm{mM} \mathrm{H}_{2} \mathrm{O}_{2}$, and then began to decline $4 \mathrm{~h}$ after addition, coinciding with the recovery in growth. It is noticeable that the induction of CAT activity showed the greatest increase. Though not directly connected with $\mathrm{H}_{2} \mathrm{O}_{2}$ detoxification, intracellular SOD activity was also enhanced. Its maximum appeared $8 \mathrm{~h}$ after addition of $10 \mathrm{mM} \mathrm{H}_{2} \mathrm{O}_{2}$, and SOD activity declined more slowly compared with the other three intracellular antioxidant enzymes. This is consistent with other reports which proposed that SOD activity is mainly induced by superoxide, but could be increased moderately by $\mathrm{H}_{2} \mathrm{O}_{2}$ [14]. The intrinsic connection of these two stresses is still ambiguous, and we propose that addition of $\mathrm{H}_{2} \mathrm{O}_{2}$ to living cultures, especially in large quantities, may lead to an overabundance of molecular oxygen when $\mathrm{H}_{2} \mathrm{O}_{2}$ is dismutated to $\mathrm{H}_{2} \mathrm{O}$ and $\mathrm{O}_{2}$ by CAT. By contrast, addition of $\mathrm{H}_{2} \mathrm{O}_{2}$ at lethal doses failed to induce these activities. As shown in Table 1, activities of SOD, CAT, and GR fell significantly after addition of $10 \mathrm{mM} \mathrm{H}_{2} \mathrm{O}_{2}$ to unadapted cultures, while adding $20 \mathrm{mM} \mathrm{H}_{2} \mathrm{O}_{2}$ to such cultures reduced activities to almost unmeasurable levels. Therefore, the induction of antioxidant enzymes activities is essential for the cells to acquire the ability to adapt to $\mathrm{H}_{2} \mathrm{O}_{2}$.

Fig. 4 shows the changes in the concentrations of GSH and GSSG in response to $\mathrm{H}_{2} \mathrm{O}_{2}$ addition. Compared to the control, both 
(A)
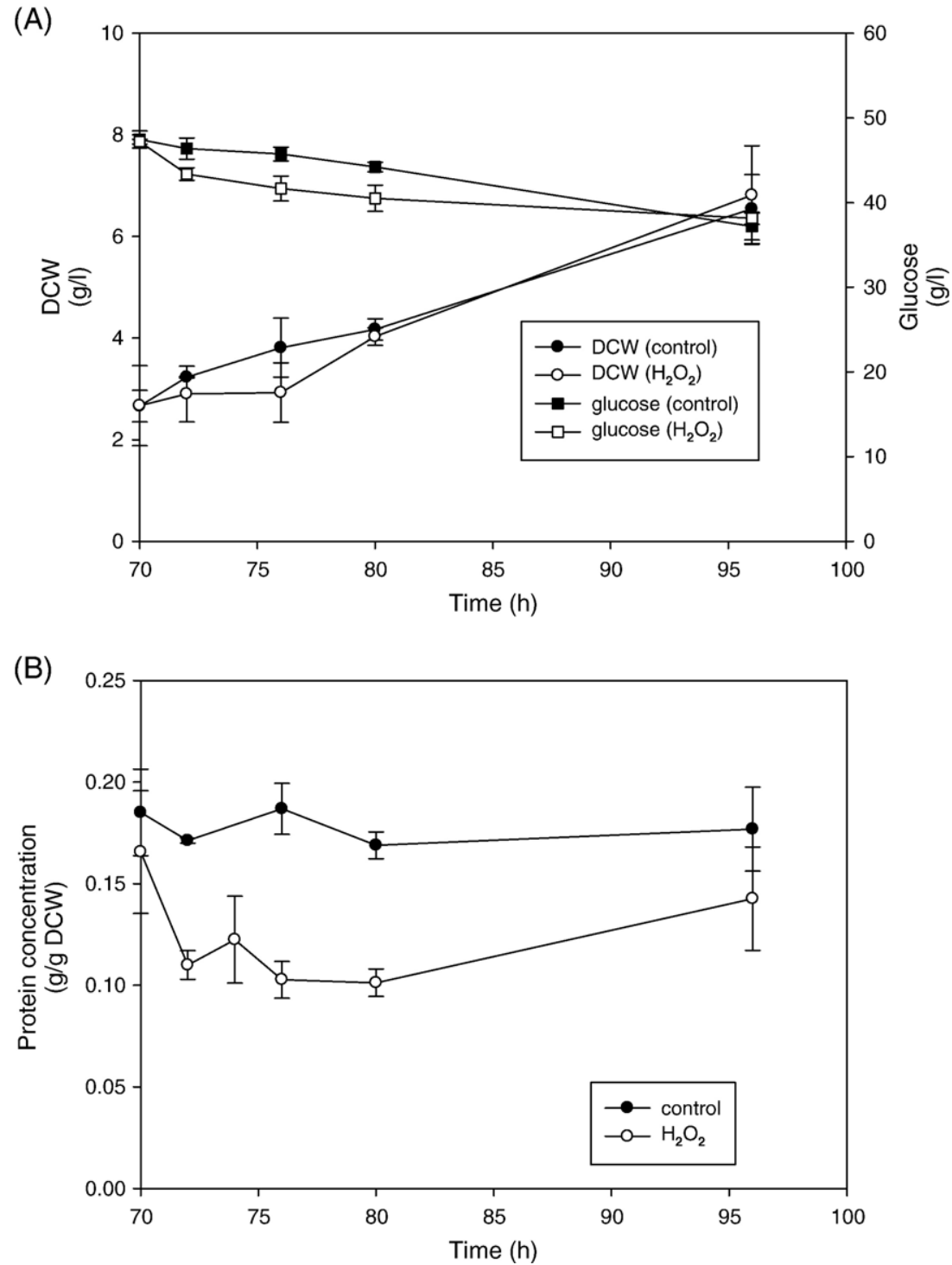

Fig. 2. Effect of $\mathrm{H}_{2} \mathrm{O}_{2}$ addition on the dry cell weight (DCW), glucose concentration, and intracellular protein content in batch cultures of $A$. niger $\mathrm{B} 1-\mathrm{D}$. $\mathrm{H}_{2} \mathrm{O}_{2}$ was added to the culture at 70 and $72 \mathrm{~h}$, to final concentrations of $100 \mu \mathrm{M}$ and $10 \mathrm{mM}$, respectively. The results were obtained from three independents experiments and expressed as mean $\pm \mathrm{SD}$.

GSH and GSSG concentrations increased significantly following addition of $100 \mu \mathrm{M} \mathrm{H}_{2} \mathrm{O}_{2}$, and then $10 \mathrm{mM} \mathrm{H}_{2} \mathrm{O}_{2}$, but the ratio of GSH/GSSG decreased. These results indicate that glutathione is implicated in oxidative defence against $\mathrm{H}_{2} \mathrm{O}_{2}$ in A. niger.

Fig. 5 shows the changes in $\mathrm{H}_{2} \mathrm{O}_{2}$ concentrations in the culture fluid during the process of culture adaptation. The detoxification of $10 \mathrm{mM} \mathrm{H}_{2} \mathrm{O}_{2}$ in the adapted culture is significantly faster than in the unadapted cultures. This is probably due to the significant induction of antioxidant enzymes activities in the adapted culture, and the marked decrease in such activities in undapted cultures. Altogether, these results strongly support the view that the acquisition of $\mathrm{H}_{2} \mathrm{O}_{2}$ tolerance was due to increased capacity to remove the oxidant itself, thus avoiding prolonged exposure to $\mathrm{H}_{2} \mathrm{O}_{2}$ and associated deleterious intracellular events. Further, it has been proposed that the decomposition rate of exogenous $\mathrm{H}_{2} \mathrm{O}_{2}$ by intact viable cells is a first-order reaction [33]: this implies that the decline in $\mathrm{H}_{2} \mathrm{O}_{2}$ concentration in the cultures should be exponential. In the present study, we found that the detoxification profile of $100 \mu \mathrm{M} \mathrm{H}_{2} \mathrm{O}_{2}$ in cultures of $A$. niger did indeed follow this trend, as supported by the high value of $R^{2}$, as did the detoxification profile of $10 \mathrm{mM} \mathrm{H}_{2} \mathrm{O}_{2}$ in adapted cultures, but not in unadapted cultures (Fig. 5B).

\section{Discussion}

\section{Adaptation to $\mathrm{H}_{2} \mathrm{O}_{2}$}

The intracellular concentration of $\mathrm{H}_{2} \mathrm{O}_{2}$ in aerobically growing Escherichia coli is estimated between 0.1 and $1 \mu \mathrm{M}$ [34]. In the present work, we found that $A$. niger is able to cope with up to $100 \mu \mathrm{M}$ exogenous $\mathrm{H}_{2} \mathrm{O}_{2}$, and adapt to up to $20 \mathrm{mM}$ 
(A)
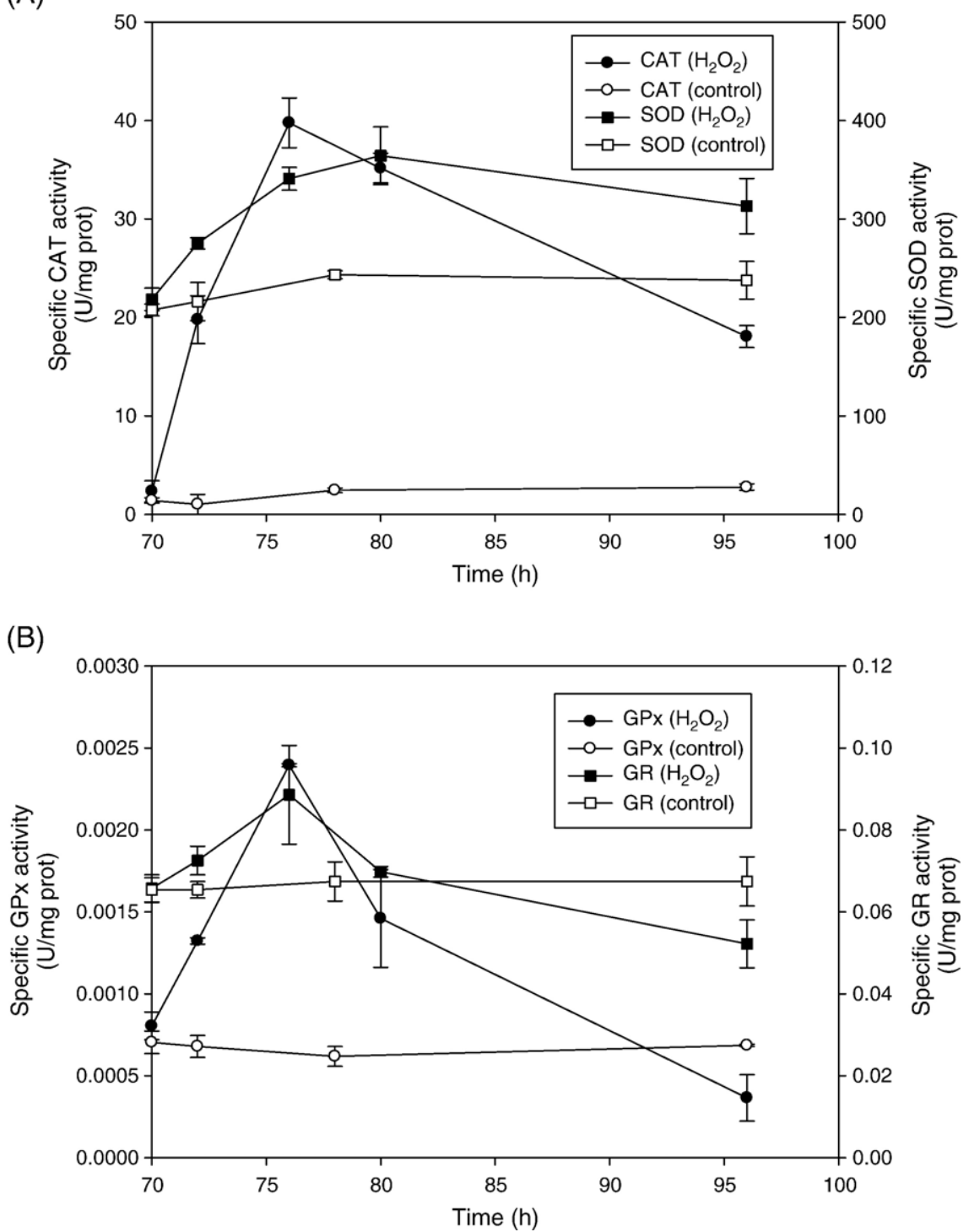

Fig. 3. Effect of $\mathrm{H}_{2} \mathrm{O}_{2}$ addition on the activities of antioxidant enzymes in batch cultures of A. niger $\mathrm{B} 1-\mathrm{D} . \mathrm{H}_{2} \mathrm{O}_{2}$ was added to the culture at 70 and $72 \mathrm{~h}$, to final concentrations of $100 \mu \mathrm{M}$ and $10 \mathrm{mM}$, respectively. The results were obtained from three independent experiments, and expressed as mean \pm SD.

following preexposure. A $100 \mu \mathrm{M} \mathrm{H}_{2} \mathrm{O}_{2}$ leads to a temporary growth arrest and a decrease in protein content. Previous work in A. niger showed that protein concentrations decreased under conditions of oxidative stress [35]. In S. cerevisiae, exposure to $\mathrm{H}_{2} \mathrm{O}_{2}$ resulted in a slowdown of protein biosynthetic processes, and a stimulation of protein degradation pathways [36]. However, despite a general decline in protein content, some antioxidant enzymes activities could be greatly enhanced. In the present study, we showed induction of CAT, SOD, GPx, and GR activities by exogenous $\mathrm{H}_{2} \mathrm{O}_{2}$ in $A$. niger. On the other hand, direct addition of high concentrations of $\mathrm{H}_{2} \mathrm{O}_{2}$ failed to induce these activities. Meanwhile, we showed that detoxification of $\mathrm{H}_{2} \mathrm{O}_{2}$ in the adapted culture is by far more rapid compared with the unadapted cultures. Therefore, we propose that the induction of these enzymes is the mechanism by which such cultures acquire tolerance to high (potentially lethal) concentrations of $\mathrm{H}_{2} \mathrm{O}_{2}$ in A. niger. More importantly, we have demonstrated that this tolerance is simply due to a rapid detoxification of exogenous $\mathrm{H}_{2} \mathrm{O}_{2}$, avoiding prolonged exposure and associated intracellular damage.

A number of papers have reported the induction of antioxidant enzymes activities by $\mathrm{H}_{2} \mathrm{O}_{2}$ in microorganisms [29,37,38], but the time course effects of $\mathrm{H}_{2} \mathrm{O}_{2}$ are not discussed. However,

Table 1

Effects of direct addition of $\mathrm{H}_{2} \mathrm{O}_{2}(10$ or $20 \mathrm{mM})$ on the activities of antioxidant enzymes in batch cultures of $A$. niger $\mathrm{B} 1-\mathrm{D}$

\begin{tabular}{llll}
\hline & CAT u/mg prot & SOD u/mg prot & GR mu/mg prot \\
\hline Control & $2.61 \pm 0.22$ & $246.3 \pm 10.0$ & $88.9 \pm 5.0$ \\
$10 \mathrm{mM} \mathrm{H}_{2} \mathrm{O}_{2}$ & $1.65 \pm 0.15$ & $31.7 \pm 9.6$ & $69.1 \pm 6.6$ \\
$20 \mathrm{mM} \mathrm{H}_{2} \mathrm{O}_{2}$ & N.D. & N.D. & $9.0 \pm 1.4$ \\
\hline
\end{tabular}

$\mathrm{H}_{2} \mathrm{O}_{2}$ was added at $72 \mathrm{~h}$ at the indicated concentrations, and incubated for $4 \mathrm{~h}$ Results were obtained from three independent experiments and expressed as mean $\pm \mathrm{SD}$ 


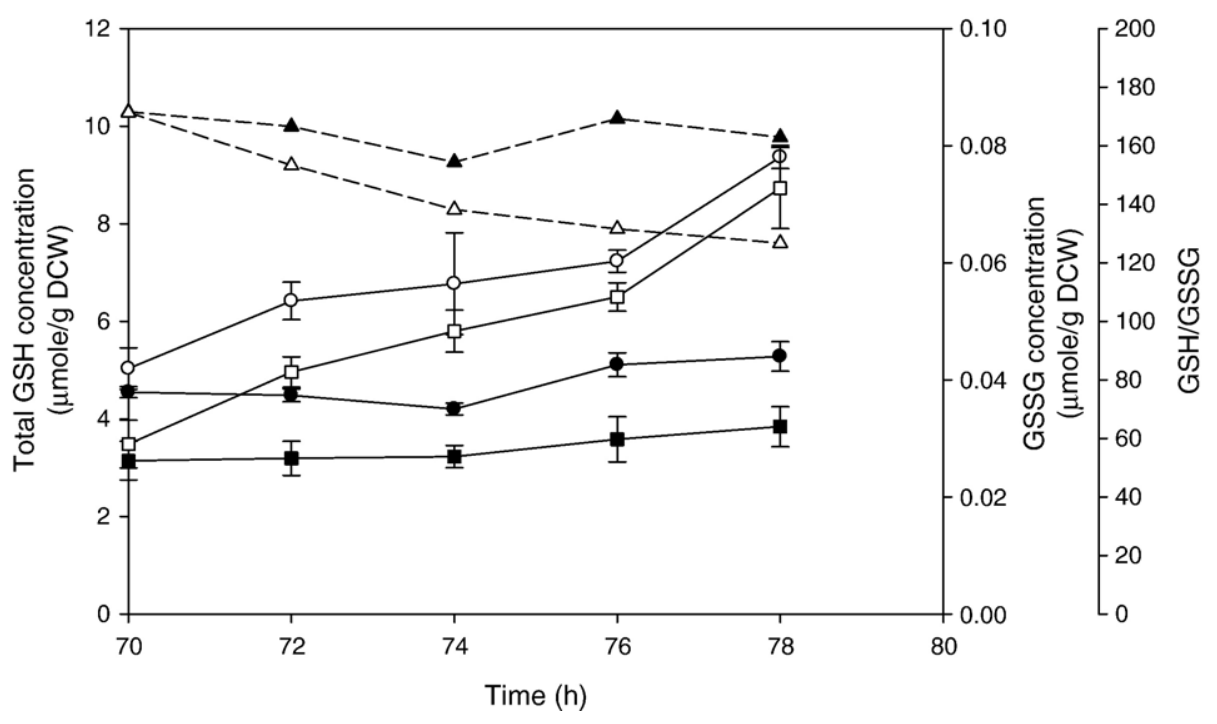

Fig. 4. Effect of $\mathrm{H}_{2} \mathrm{O}_{2}$ addition on the GSH and GSSG in batch cultures of A. niger B1-D. $\mathrm{H}_{2} \mathrm{O}_{2}$ was added to the culture at 70 and $72 \mathrm{~h}$, to final concentrations of $100 \mu \mathrm{M}$ and $10 \mathrm{mM}$, respectively. GSH (control); $\mathrm{O} \mathrm{GSH}\left(\mathrm{H}_{2} \mathrm{O}_{2}\right)$; $\boldsymbol{G S S G}$ (control); $\square \mathrm{GSSG}\left(\mathrm{H}_{2} \mathrm{O}_{2}\right) ; \boldsymbol{\Delta} \mathrm{GSH} / \mathrm{GSSG}$ (control); $\triangle \mathrm{GSH} / \mathrm{GSSG}\left(\mathrm{H}_{2} \mathrm{O}_{2}\right)$. The results were obtained from three independent experiments and expressed as mean $\pm \mathrm{SD}$.

monitoring the changes in exogenous $\mathrm{H}_{2} \mathrm{O}_{2}$ levels with time is a key factor in attempting to understand the process of adaptation. Our results show that the antioxidant enzymes activities, those involved in the $\mathrm{H}_{2} \mathrm{O}_{2}$ detoxification, including CAT, GPx, and GR, peaked $4 \mathrm{~h}$ after addition of $10 \mathrm{mM} \mathrm{H}_{2} \mathrm{O}_{2}$ (Fig. 3). The decline in activity of these enzymes coincides with the recovery from growth arrest, meaning that cells are shifting from oxidative defence back to growth. This indicates that the cells may not keep the ability to tolerate severe $\mathrm{H}_{2} \mathrm{O}_{2}$ stress permanently. Overproduction of these antioxidant enzymes requires extra energy [24], so it makes sense that these enzyme activities are decreasing after exogenous $\mathrm{H}_{2} \mathrm{O}_{2}$ is completely detoxified, in order to avoid wasting energy. The mechanism through which this decline takes place is still obscure, but from our findings it is clear that activities of these antioxidant enzymes do not correlate well with endogenous $\mathrm{H}_{2} \mathrm{O}_{2}$ concentrations, since the complete removal of $10 \mathrm{mM} \mathrm{H}_{2} \mathrm{O}_{2}$ took places less than $1 \mathrm{~h}$ after addition in the adapted culture (Fig. 5), while the defensive enzyme activities remained high for much longer (Fig. 3).

\section{$C A T$ and $G P x$}

In filamentous fungi, two peroxidases, CAT and GPx, have been reported to be associated with $\mathrm{H}_{2} \mathrm{O}_{2}$ detoxification. CAT catalyses the decomposition of $\mathrm{H}_{2} \mathrm{O}_{2}$ to water and oxygen, while GPx reduces peroxide at the expense of GSH and NADPH $[13,14,20]$. The relative extent to which these two enzymes contribute to $\mathrm{H}_{2} \mathrm{O}_{2}$ detoxification is still unclear. Our results show the prestressed level of GPx activity is far less than that of CAT. Similar results have been reported by a number of research groups using different organisms, such as $P$. chrysogenum [20], Candida albicans [38], and S. cerevisiase [8,9]. In addition, in the present study CAT activity increased 8.5 -fold on addition of $100 \mu \mathrm{M} \mathrm{H}_{2} \mathrm{O}_{2}$, while GPx only rose by a factor of 1.6 . Here, we propose that CAT plays more important role in $\mathrm{H}_{2} \mathrm{O}_{2}$
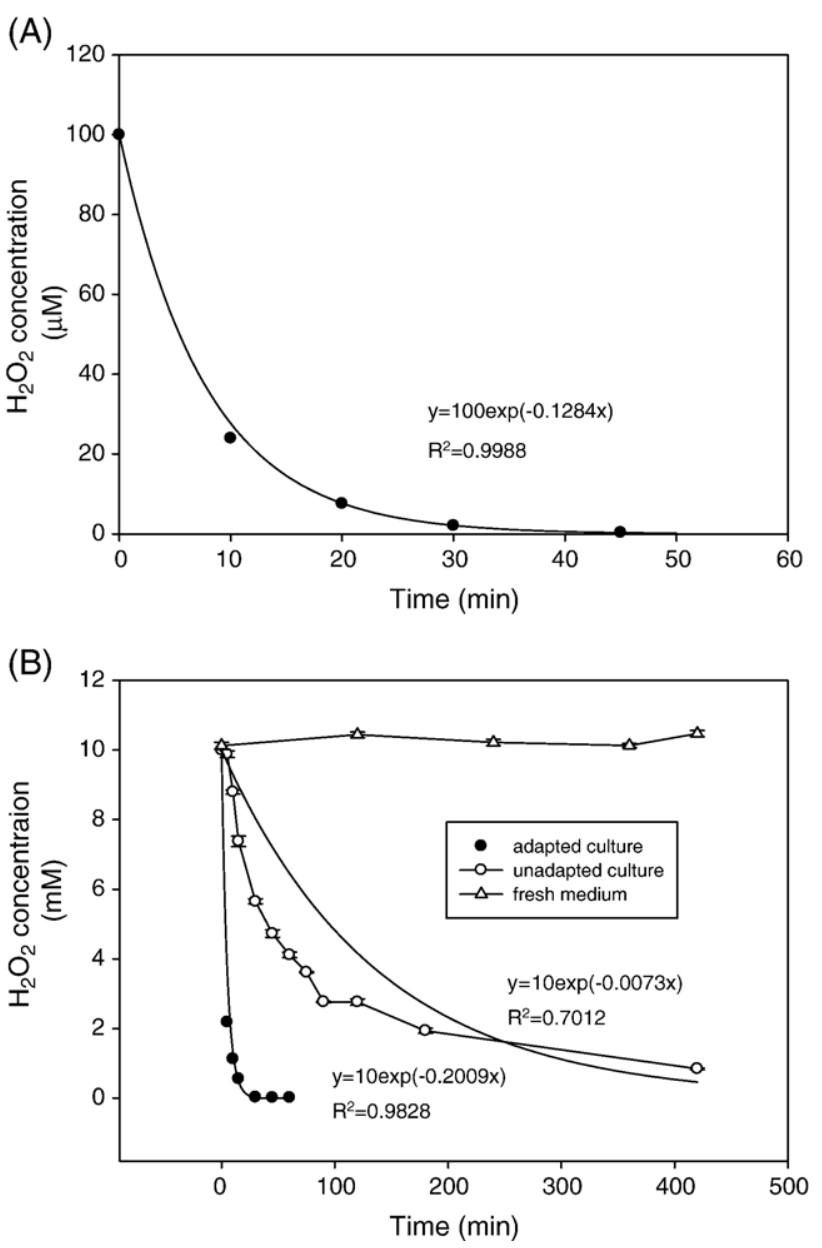

Fig. 5. $\mathrm{H}_{2} \mathrm{O}_{2}$ detoxification in batch cultures of A. niger $\mathrm{B} 1-\mathrm{D}$. (A) $\mathrm{H}_{2} \mathrm{O}_{2}$ was added to batch culture at $70 \mathrm{~h}$ to final concentration of $100 \mu \mathrm{M}$. (B) $\mathrm{H}_{2} \mathrm{O}_{2}$ was added to batch culture, adapted (pretreatment with $100 \mu \mathrm{M} \mathrm{H}_{2} \mathrm{O}_{2}$ for $2 \mathrm{~h}$ ) or not, at $72 \mathrm{~h}$ to final concentration of $10 \mathrm{mM}$. The results were obtained from three independent experiments and expressed as mean $\pm \mathrm{SD}$. 
detoxification in filamentous fungi. However, GPx has been shown to be indispensable in coping with stress induced by the addition of other peroxides, such as tert-butyl hydroperoxide ( $t$ BHP), which cannot be detoxified by CAT [20]. In S. cerevisiae, a mutant with deleted CAT genes $(\operatorname{ctt} 1 \Delta / \operatorname{ctal} \Delta)$ grew similarly to the wild type under nonoxidative stress conditions, and showed a similar susceptibility to $\mathrm{H}_{2} \mathrm{O}_{2}$, but its ability to adapt to $\mathrm{H}_{2} \mathrm{O}_{2}$ had been severely compromised [9]. On the other hand, a mutant carrying deletion of a GPx homologous gene was hypersensitive to both $\mathrm{H}_{2} \mathrm{O}_{2}$ and $t$-BHP [8]. In the wild type, the basal mRNA level of that gene was high, and the product of the gene was expressed constitutively [8]. From these results and our own findings, we hypothesize that, in fungi, CAT and GPx contribute to $\mathrm{H}_{2} \mathrm{O}_{2}$ detoxification at the same time under (normal) nonstress conditions, but CAT plays a more significant role in dealing with sudden bursts of $\mathrm{H}_{2} \mathrm{O}_{2}$, not only due to its overwhelmingly higher capacity to remove $\mathrm{H}_{2} \mathrm{O}_{2}$ but also the cells ability to rapidly boost the activity of this enzyme in response to $\mathrm{H}_{2} \mathrm{O}_{2}$. This adaptive capability has an intrinsic, central role in many areas of fungal life; for example, CAT has been shown to be implicated in the virulence of some fungi, in which the high capacity of the fungal cells to remove $\mathrm{H}_{2} \mathrm{O}_{2}$ is essential to counteract the burst of ROS generated by the host cells to kill the invading fungal pathogens [39].

\section{Glutathione pathways (GPx, GR, GSH/GSSG)}

The effect of $\mathrm{H}_{2} \mathrm{O}_{2}$ addition on GR follows the same trend as that of GPx. However, it is worth noting that the reductase activities are much higher than the peroxidase activities. Meanwhile, the redox state of glutathione, expressed as the ratio between the reduced from to the oxidized form, GSH/GSSG, is over 100. It has been reported that the redox state of glutathione in fungi is usually above 20 [40]. Here we show that this figure is higher in this $A$. niger, and the reduced state of glutathione corresponds to a high ratio of reductase activity to peroxidase activity.

Our results also clearly show that GSH does play a role in oxidative defence in A. niger. On the one hand, GSH reduces intracellular oxidants by reacting with them, enzymatically or nonenzymatically [40]. By contrast, GSH synthesis is boosted in attempting to rectify the imbalance of glutathione homeostasis. Emri et al. [20] showed that there were no significant changes in GSH levels in response to $\mathrm{H}_{2} \mathrm{O}_{2}$. The extremely high concentration of $\mathrm{H}_{2} \mathrm{O}_{2}(0.35$ and $0.7 \mathrm{M})$ used in their work might account for this discrepancy; as we demonstrated here different concentrations of $\mathrm{H}_{2} \mathrm{O}_{2}$ impose distinct effects on microorganisms.

\section{Estimation of intracellular concentration of $\mathrm{H}_{2} \mathrm{O}_{2}$}

According to previous studies, $\mathrm{H}_{2} \mathrm{O}_{2}$ does not freely diffuse across biomembranes, and the fast removal of $\mathrm{H}_{2} \mathrm{O}_{2}$ by intracellular antioxidant enzymes is able to generate a concentration gradient between extracellular and intracellular milieu $[4,33]$. It is this gradient which provides the driving force for $\mathrm{H}_{2} \mathrm{O}_{2}$ entering the cells where it is decomposed. The intracellular concentration of $\mathrm{H}_{2} \mathrm{O}_{2}$ is usually much lower than the external one.
Under in vivo conditions, both CAT [41] and GPx [42] displayed first-order kinetics with their substrates, not exhibiting saturation effects. As such, the ratio between the concentration of intracellular and extracellular $\mathrm{H}_{2} \mathrm{O}_{2}$ is described by the [33]

$\left[\mathrm{H}_{2} \mathrm{O}_{2}\right]_{\text {in }} /\left[\mathrm{H}_{2} \mathrm{O}_{2}\right]_{\text {out }}=R=k_{\text {app }} /\left(k_{\mathrm{GPx}}+k_{\mathrm{CAT}}\right)$,

where $k_{\text {app }}$ refers to the first-order rate constant of the apparent decomposition rate by intact cells, and $k_{\mathrm{GPx}}$ and $k_{\mathrm{CAT}}$ refer to the first-order rate constants of GPx and CAT in the cell-free extract, respectively [33]. In the present study, we found that intracellular CAT activity is overwhelmingly higher than that of GPx. So the equation can be simplified to

$\left[\mathrm{H}_{2} \mathrm{O}_{2}\right]_{\text {in }} /\left[\mathrm{H}_{2} \mathrm{O}_{2}\right]_{\text {out }}=R=k_{\text {app }} / k_{\text {CAT }}$.

Further, $k_{\mathrm{CAT}}$ could be derived from intracellular CAT activity in the cell-free extract. In present study, one unit of CAT activity is defined as the decomposition of one micromole $\mathrm{H}_{2} \mathrm{O}_{2}$ in one minute in the presence of $10 \mathrm{mM} \mathrm{H}_{2} \mathrm{O}_{2}$ [27]. The value of the CAT activity $\left(U_{\mathrm{CAT}}, \mathrm{U} / \mathrm{ml}\right)$ measured in this assay is equal to that of the initial decomposition rate of $\mathrm{H}_{2} \mathrm{O}_{2}$ by the CAT $(\mathrm{mM} / \mathrm{min})$.

$r_{0}=k_{\mathrm{CAT}} C_{0}$

$k_{\mathrm{CAT}}=r_{0} / C_{0}=U_{\mathrm{CAT}} / C_{0}=U_{\mathrm{CAT}} / 10$,

where $r_{0}$ refers to the initial rate, when the initial substrate concentration is $10 \mathrm{mM}\left(C_{0}\right)$. Finally, the gradient could be derived as

$\left[\mathrm{H}_{2} \mathrm{O}_{2}\right]_{\text {in }} /\left[\mathrm{H}_{2} \mathrm{O}_{2}\right]_{\text {out }}=R=10 k_{\text {app }} / U_{\mathrm{C}}$

The estimated gradient is a lower limit, because only CAT is considered for $\mathrm{H}_{2} \mathrm{O}_{2}$ detoxification in our model; if other enzymes consume $\mathrm{H}_{2} \mathrm{O}_{2}$, the gradient will be steeper. Nevertheless, our model gives us valuable insights into the profile of the intracellular concentration of $\mathrm{H}_{2} \mathrm{O}_{2}$ which is distinct from the extracellular one. $k_{a p p}$ and $k_{\mathrm{CAT}}$ from adapted and unadapted $A$. niger are described in Table 2 . There is a relatively small gradient between intracellular and extracellular $\mathrm{H}_{2} \mathrm{O}_{2}$ concentrations when $100 \mu \mathrm{M} \mathrm{H}_{2} \mathrm{O}_{2}$ is added. This suggests the rate at which exogenous $\mathrm{H}_{2} \mathrm{O}_{2}$ entering the cells is beyond their capacity to remove it, and accumulation of $\mathrm{H}_{2} \mathrm{O}_{2}$ inside the cells occurs quickly. By contrast, the estimated gradient in the

Table 2

First-order constants of apparent decomposition rate of $\mathrm{H}_{2} \mathrm{O}_{2}$ by intact cells, $k_{\text {app}}$; first order constants of decomposition rate of $\mathrm{H}_{2} \mathrm{O}_{2}$ by CAT in cell-free extract, $k_{\text {CAT }} ; \mathrm{H}_{2} \mathrm{O}_{2}$ concentration gradient between intracellular and extracellular milieu

\begin{tabular}{llll}
\hline & $k_{\text {app }}$ & $k_{\mathrm{CAT}}$ & {$\left[\mathrm{H}_{2} \mathrm{O}_{2}\right]_{\text {in }} /\left[\mathrm{H}_{2} \mathrm{O}_{2}\right]_{\text {out }}$} \\
\hline $100 \mu \mathrm{M}$ & 0.1284 & 0.154 & 0.834 \\
$10 \mathrm{mM}$ & 0.2009 & 0.758 & 0.265 \\
\hline
\end{tabular}

$100 \mu \mathrm{M} \mathrm{H}_{2} \mathrm{O}_{2}$ was added to batch culture of $A$. niger B1-D at $70 \mathrm{~h}$ (unadapted) $10 \mathrm{mM} \mathrm{H}_{2} \mathrm{O}_{2}$ was added to batch culture of $A$. niger $\mathrm{B} 1-\mathrm{D}$ pre-treated with $100 \mu \mathrm{M} \mathrm{H}_{2} \mathrm{O}_{2}$ for $2 \mathrm{~h}$ at $72 \mathrm{~h}$. 
adapted culture is much higher than in unadapted cultures. This shows that $A$. niger has a greatly enhanced capacity to remove $\mathrm{H}_{2} \mathrm{O}_{2}$ after adaptation, and the cells' ability to remove $\mathrm{H}_{2} \mathrm{O}_{2}$ becomes comparable to the rate of $\mathrm{H}_{2} \mathrm{O}_{2}$ entering the cells. Thus, accumulation of this oxidant inside the cells is avoided. By gaining new insights into the detoxification rate of exogenous $\mathrm{H}_{2} \mathrm{O}_{2}$ by intact adapted cells, and into the intracellular antioxidant enzyme activities, we have shown that enhanced degradation of $\mathrm{H}_{2} \mathrm{O}_{2}$, which alters the concentration gradient of the stressor and minimises intracellular accumulation, is the mechanism of the adaptive effect.

\section{Conclusions}

Pretreatment of $A$. niger with $\mathrm{H}_{2} \mathrm{O}_{2}$ at a nonlethal concentration confers greatly enhanced resistance to killing by $\mathrm{H}_{2} \mathrm{O}_{2}$ at lethal concentrations in the early exponential phase of growth. This adaptation involves the induction of a number of antioxidant enzymes, predominantly catalase. Enhancement of the activities of these antioxidant enzymes prevents accumulation of $\mathrm{H}_{2} \mathrm{O}_{2}$ inside the cells, as supported by the increased decomposition rate of external $\mathrm{H}_{2} \mathrm{O}_{2}$ by intact cells, and higher gradient of $\mathrm{H}_{2} \mathrm{O}_{2}$ concentration between intracellular and extracelluar milieu estimated from a mathematical model.

\section{Acknowledgments}

Qiang Li thanks ORS and University of Strathclyde for financial support. He also thanks Dr. Zhonghu Bai for invaluable discussions.

\section{References}

[1] Turrens, J. F. Mitochondrial formation of reactive oxygen species. $J$. Physiol. 552 (2):335 344; 2003.

[2] Dalton, T. P.; Shertzer, H. G.; Puga, A. Regulation of gene expression by reactive oxygen. Annu. Rev. Pharmacol. Toxicol. 39:67 101; 1999.

[3] Jamieson, D. J. Oxidative stress responses of the yeast Saccharomyces cerevisiae. Yeast 14 (16): 1511 1527; 1998.

[4] Branco, M. R.; Marinho, H. S.; Cyrne, L.; Antunes, F. Decrease of $\mathrm{H}_{2} \mathrm{O}_{2}$ plasma membrane permeability during adaptation to $\mathrm{H}_{2} \mathrm{O}_{2}$ in Saccharomyces cerevisiae. J. Biol. Chem. 279 (8):6501 6506; 2004.

[5] Imlay, J. A. Pathways of oxidative damage. Annu. Rev. Microbiol. 57:395 418; 2003.

[6] Izawa, S.; Maeda, K.; Miki, T.; Mano, J.; Inoue, Y.; Kimura, A. Importance of glucose-6-phosphate dehydrogenase in the adaptive response to hydrogen peroxide in Saccharomyces cerevisiae. Biochem. J. 330 (2):811 817; 1998.

[7] Minard, K. I.; McAlister-Henn, L. Antioxidant function of cytosolic sources of NADPH in yeast. Free Radic. Biol. Med. 31 (6):832 843; 2001.

[8] Inoue, Y.; Matsuda, T.; Sugiyama, K.; Izawa, S.; Kimura, A. Genetic analysis of glutathione peroxidase in oxidative stress response of Saccharomyces cerevisiae. J. Biol. Chem. 274 (38):27002 27009; 1999.

[9] Izawa, S.; Inoue, Y.; Kimura, A. Importance of catalase in the adaptive response to hydrogen peroxide: analysis of acatalasaemic Saccharomyces cerevisiae. Biochem. J. 320 (1):61 67; 1996.

[10] Navarro, R. E.; Stringer, M. A.; Hansberg, W.; Timberlake, W. E.; Aguirre, J. catA, a new Aspergillus nidulans gene encoding a developmentally regulated catalase. Curr. Genet. 29 (4):352 359; 1996.

[11] Kawasaki, L.; Wysong, D.; Diamond, R.; Aguirre, J. Two divergent catalase genes are differentially regulated during Aspergillus nidulans development and oxidative stress. J. Bacteriol. 179 (10):3284 3292; 1997.

[12] Navarro, R. E.; Aguirre, J. Posttranscriptional control mediates cell typespecific localization of catalase A during Aspergillus nidulans development. J. Bacteriol. 180 (21):5733 5738; 1998.

[13] Kreiner, M.; Harvey, L. M.; McNeil, B. Oxidative stress response of a recombinant Aspergillus niger to exogenous menadione and $\mathrm{H}_{2} \mathrm{O}_{2}$ addition. Enzyme Microb. Technol. 30 (3):346 353; 2002.

[14] Angelova, M. B.; Pashova, S. B.; Spasova, B. K.; Vassilev, S. V.; Slokoska, L. S. Oxidative stress response of filamentous fungi induced by hydrogen peroxide and paraquat. Mycol. Res. 109 (2):150 158; 2005.

[15] Stephen, D. W.; Jamieson, D. J. Glutathione is an important antioxidant molecule in the yeast Saccharomyces cerevisiae. FEMS Microbiol. Lett. 141 (2 3):207 212; 1996.

[16] Izawa, S.; Inoue, Y.; Kimura, A. Oxidative stress response in yeast: effect of glutathione on adaptation to hydrogen peroxide stress in Saccharomyces cerevisiae. FEBS Lett. 368 (1):73 76; 1995.

[17] Lee, J. C.; Straffon, M. J.; Jang, T. Y.; Higgins, V. J.; Grant, C. M.; Dawes, I. W. The essential and ancillary role of glutathione in Saccharomyces cerevisiae analysed using a grande gsh1 disruptant strain. FEMS Yeast Res. 1 (1):57 65; 2001.

[18] Grant, C. M.; Collinson, L. P.; Roe, J. H.; Dawes, I. W. Yeast glutathione reductase is required for protection against oxidative stress and is a target gene for yAP-1 transcriptional regulation. Mol. Microbiol. 21 (1):171 179; 1996.

[19] Bai, Z.; Harvey, L. M.; McNeil, B. Elevated temperature effects on the oxidant/antioxidant balance in submerged batch cultures of the filamentous fungus Aspergillus niger B1-D. Biotechnol. Bioeng. 83 (7):772 779; 2003.

[20] Emri, T.; Pocsi, I.; Szentirmai, A. Glutathione metabolism and protection against oxidative stress caused by peroxides in Penicillium chrysogenum. Free Radic. Biol. Med. 23 (5):809 814; 1997.

[21] Gibbs, P. A.; Seviour, R. J.; Schmid, F. Growth of filamentous fungi in submerged culture: problems and possible solutions. Crit. Rev. Biotechnol. 20 (1):17 48; 2000.

[22] Bai, Z.; Harvey, L. M.; McNeil, B. Oxidative stress in submerged cultures of fungi. Crit. Rev. Biotechnol. 23 (4):267 302; 2003.

[23] Archer, D. B.; Jeenes, D. J.; MacKenzie, D. A.; Brightwell, G.; Lambert, N.; Lowe, G.; Radford, S. E.; Dobson, C. M. Hen egg white lysozyme expressed in, and secreted from, Aspergillus niger is correctly processed and folded. Bio/Technology 8:741 745; 1990.

[24] Bai, Z.; Harvey, L. M.; McNeil, B. Physiological responses of chemostat cultures of Aspergillus niger B1-D to simulated and actual oxidative stress. Biotechnol. Bioeng. 82 (6):691 701; 2003.

[25] Wolff, S. P.; Lester, P. Ferrous ion oxidation in presence of ferric ion indicator xylenol orange for measurement of hydroperoxides. In: Packer, L. (Ed.), Oxygen radicals in biological systems, part C. Methods in enzymology, vol. 233. Academic Press, San Diego, pp. 182 189; 1994.

[26] Crapo, J. D.; McCord, J. M.; Fridovich, I. Preparation and assay of superoxide dismutases. In: Fleishcher, S., Packer, L. (Eds.), Biomembranes, part D. Methods in enzymology, vol. 53. Academic Press, San Diego,pp. 382 393; 1978.

[27] Aebi, H. Catalase in vitro. In: Packer, L. (Ed.), Oxygen radicals in biological systems, methods in enzymology, vol. 105. Academic Press, San Diego,pp. 121 126; 1984.

[28] Tappel, A. L. Glutathione peroxidase and hydroperoxides. In: Fleishcher, S., Packer, L. (Eds.), Biomembranes, part C. Methods in enzymology, vol. 52. Academic Press, San Diego, pp. 506 513; 1978.

[29] Lee, J.; Dawes, I. W.; Roe, J. H. Adaptive response of Schizosaccharomyces pombe to hydrogen peroxide and menadione. Microbiology 141 (12):3127 3132; 1995 .

[30] Anderson, M. E. Determination of glutathione and glutathione disulfide in biological samples. In: Meiser, A. (Ed.), Glutamate, glutamine, glutathione, and related compounds. Methods in enzymology, vol. 113. Academic Press, San Diego, pp. 548 555; 1985.

[31] Bradford, M. M. A rapid and sensitive method for the quantitation of microgram quantities of protein utilizing the principle of protein-dye binding. Anal. Biochem. 72:248 254; 1976. 
[32] Emri, T.; Molnar, Z.; Pocsi, I. The appearances of autolytic and apoptotic markers are concomitant but differently regulated in carbon-starving Aspergillus nidulans cultures. FEMS Microbiol. Lett. 251 (2):297 303; 2005.

[33] Antunes, F.; Cadenas, E. Estimation of $\mathrm{H}_{2} \mathrm{O}_{2}$ gradients across biomembranes. FEBS Lett. 475 (2):121 126; 2000.

[34] Storz, G.; Imlay, J. A. Oxidative stress. Curr. Opin. Microbiol. 2 (2):188 194; 1999.

[35] Bai, Z.; Harvey, L. M.; White, S.; McNeil, B. Effects of oxidative stress on production of heterologous and native protein, and culture morphology in batch and chemostat cultures of Aspergillus niger B1-D. Enzyme Microb. Technol. 34 (1):10 21; 2004

[36] Godon, C.; Lagniel, G.; Lee, J.; Buhler, J. M.; Kieffer, S.; Perrot, M.; Boucherie, H.; Toledano, M. B.; Labarre, J. The $\mathrm{H}_{2} \mathrm{O}_{2}$ stimulon in Saccharomyces cerevisiae. J. Biol. Chem. 273 (35):22480 22489; 1998.
[37] Davies, J. M.; Lowry, C. V.; Davies, K. J. Transient adaptation to oxidative stress in yeast. Arch. Biochem. Biophys. 317 (1):1 6; 1995.

[38] Jamieson, D. J.; Stephen, D. W.; Terriere, E. C. Analysis of the adaptive oxidative stress response of Candida albicans. FEMS Microbiol. Lett. 138 (1):83 88; 1996.

[39] Hamilton, A. J.; Holdom, M. D. Antioxidant systems in the pathogenic fungi of man and their role in virulence. Med. Mycol. 37 (6):375 389; 1999.

[40] Pocsi, I.; Prade, R. A.; Penninckx, M. J. Glutathione, altruistic metabolite in fungi. Adv. Microb. Physiol. 49:1 76; 2004.

[41] Chance, B.; Sies, H.; Boveris, A. Hydroperoxide metabolism in mammalian organs. Physiol. Rev. 59 (3):527 605; 1979.

[42] De Duve, C. The separation and characterization of subcellular particles. Harvey Lect. 59:49 87; 1965. 